Tropical Journal of Pharmaceutical Research December 2014; 13 (12): 2039-2045

ISSN: $1596-5996$ (print); 1596-9827 (electronic)

(c) Pharmacotherapy Group, Faculty of Pharmacy, University of Benin, Benin City, 300001 Nigeria.

All rights reserved.

Available online at http://www.tjpr.org

Original Research Article

http://dx.doi.org/10.4314/tjpr.v13i12.14

\title{
Diuretic Activity of Achyranthes aspera Linn Crude Aqueous Extract in Albino Rats
}

\author{
Muhammad Asif $^{1 *}$, Qaiser Jabeen ${ }^{2}$, Muhammad Atif ${ }^{2}$, Amin Malik Shah Abdul \\ Majid ${ }^{1}$ and Muhammad Qamar-Uz-Zaman ${ }^{2}$ \\ ${ }^{1}$ School of Pharmaceutical Sciences, Universiti Sains Malaysia, 11800, Minden, Penang, Malaysia, ${ }^{2}$ Department of Pharmacy, \\ The Islamia University of Bahawalpur, Punjab, Pakistan
}

*For correspondence: Email: asif_pharmacist45@yahoo.com; Tel: +60125303242

Revised accepted: 17 October 2014

\begin{abstract}
Purpose: To evaluate the diuretic activity and acute toxicity profile of the crude aqueous extract of Achyranthes aspera using animal models.

Methods: Albino rats of either sex were divided into five groups (six animals in each group). The control group received normal saline $(10 \mathrm{ml} / \mathrm{kg})$, the reference group received furosemide $(10 \mathrm{mg} / \mathrm{kg})$ and the test groups were administered different doses of the crude aqueous extract (10, 30 and $50 \mathrm{mg} / \mathrm{kg}$ ) by intra-peritoneal route, respectively. At the end of $6 \mathrm{~h}$, urine was collected and total volume of urine excreted by each rat was expressed as $\mathrm{ml} / 6 \mathrm{~h} / 100 \mathrm{~g}$ of body weight. $\mathrm{pH}$ of fresh urine samples, concentration of urinary sodium and potassium ions, Lipschitz value, diuretic index, saliuretic index and $\mathrm{Na}+/ \mathrm{K}+$ ratio were also calculated to make comparison among the groups. The acute toxicity of the crude extract was assessed in Albino mice.

Results: The findings demonstrated that the crude aqueous extract of the plant showed significant diuretic $(p<0.001)$, natriuretic $(p<0.001)$ and kaliuretic $(p<0.001)$ effects. However, during the course of the study, urinary $\mathrm{pH}$ remained unchanged. The diuretic index values for the test groups (III, IV \& V) were 2.3, 2.6 and 3.1, respectively. Lipschitz values showed that, at the dose of $50 \mathrm{mg} / \mathrm{kg}$, the crude extract showed $46 \%$ of diuretic activity as compared with furosemide. No toxic effects were observed among Albino mice even at a higher dose of $3000 \mathrm{mg} / \mathrm{kg}$.

Conclusion: The crude extract of Achyranthes aspera increases the urine volume and concentration of urinary electrolytes in a dose-dependent manner. Therefore, this plant has a diuretic potential. However, future studies should focus on isolating the phytochemical component(s) responsible for diuresis.
\end{abstract}

Keywords: Achyranthes aspera, Na+/K+ ratio, Lipschitz value, Saliuretic, Diuretic index, Natriuretic

Tropical Journal of Pharmaceutical Research is indexed by Science Citation Index (SciSearch), Scopus, International Pharmaceutical Abstract, Chemical Abstracts, Embase, Index Copernicus, EBSCO, African Index Medicus, JournalSeek, Journal Citation Reports/Science Edition, Directory of Open Access Journals (DOAJ), African Journal Online, Bioline International, Open-J-Gate and Pharmacy Abstracts

\section{INTRODUCTION}

Medicinal plants contain many known and unknown medicinally important chemical substances. According to an estimate, over $75 \%$ of the world's population still depends on plantderived medicines for the treatment of common ailments [1]. According to another estimate, approximately $80 \%$ of the world's population relies upon plants for their medication [2] and between 35,000 and 70,000 plant species are used in folk medicine worldwide [3]. At present, a lot of plants and their metabolites are being successfully used in the treatment of a variety of diseases ranging from simple headache to cancer treatment [4]. One of the reasons to use herbs as medicines is probably the presence of synergistic and/or side effects neutralizing 
combinations of phytochemical constituents [5]. Another reason for the shifting trends towards natural products is the harmful effects of synthetic chemicals.

Mostly, diuretics act by stimulating urinary output and electrolyte excretion from the body. Diuretics such as the high-ceiling/loop and thiazides diuretic are associated with several adverse effects, for example, ototoxicity, hyperuricemia, acute hypovolemia, potassium depletion, hypomagnesemia, hyponatremia, hypercalcemia, hyperglycemia, hyperlipidemia and hypersensitivity [6]. This phenomenon necessitates the search of a diuretic which is comparatively free from such unwanted effects.

Achyranthes aspera Linn (Aa) of family amaranthaceae is a perennial herb approximately 0.3 to 0.9 meter in height commonly known as Pathkanda and KhardarGuna in Pakistan. Seeds are sub-cylindrical which are shortened at apex, rounded at base, black and shining [7]. It is very common in the desert areas of Pakistan.

The seeds are traditionally used in various respiratory, gastrointestinal, skin and urinary disorders [7,8]. Many studies have been conducted to explore the phytochemical constituents of the plant. Saponins, oleanic acid, amino acids, carbohydrates, proteins, water soluble bases i.e., betaine, vitamin $\mathrm{C}$, iron, calcium and phosphorous are some of the key constituents reported by previous studies $[9,10]$.

Aa is extensively used as a diuretic agent in herbal practice. However, present scientific literature has not reported its diuretic activity. Therefore, the aim of this study was to evaluate the diuretic activity of crude aqueous extract of Achyranthes aspera Linn (Aa.Cr.) in normal Albino rat model, and determine the toxicity and effects of Aa.Cr. on excretion of urinary electrolytes.

\section{EXPERIMENTAL}

\section{Plant material and extraction}

The plant material (i.e. dried seeds) was purchased from the herbal market of Bahawalpur, Punjab, Pakistan. Foreign particles were removed from the seeds. After identification by a taxonomist, the seeds were kept in the herbarium of the Pharmacology Research Laboratory at the Department of Pharmacy, the Islamia University of Bahawalpur (IUB), Pakistan, and were assigned the voucher number AA-SD06-10-009 for future reference.

The seeds were crushed into a coarse powder with an electric grinder (National, Model MJ$176 \mathrm{NR}$, China). Approximately, $500 \mathrm{~g}$ of crushed seeds were soaked in hot water (one liter). The soaked material was kept at room temperature $\left(23-25^{\circ} \mathrm{C}\right)$ for 3 days with occasional shaking. The material was then filtered. Subsequently, the residue was again soaked in hot water for 3 days. This procedure was repeated thrice (total 9 days), and finally, the filtrate was evaporated in a rotary evaporator (Heidolph Laborota 4000efficient, Germany) under reduced pressure $(-760 \mathrm{mmHg})$ to a thick, semi-solid pasty mass of dark drown color. Aa.Cr. was dissolved in distilled water and normal saline for use in in vitro and in vivo experimentation, respectively $[11,12]$.

\section{Reference and control drugs}

We used Furosemide (Lasix, Aventis Pharma, Pakistan), and normal saline (Merck, Germany) as positive and negative controls, respectively [12].

\section{Animals and treatment}

Adult Albino rats and mice were kept in metabolic cages (Techniplast, Italy). These cages were specially designed to separate urine and faeces of the study animals. In the cages, the study animals were housed under the standard conditions of temperature, humidity and dark/light cycle (12 h/12 h). The animals were given pelleted food and drinking water ad libitum. The bedding of the animal cages was changed after every 48 hours. Aa.Cr. was administered by the intra-peritoneal (IP) route in the Albino rats for the diuretic activity, and by the oral route in mice for the acute toxicity study $[12,13]$.

\section{Phytochemical screening of the crude extract}

Preliminary screening of Aa.Cr. for a variety of secondary metabolites (flavonoids, alkaloids, coumarins, tannins, anthraquinones and saponins) was performed using standard methods [12,13].

\section{Assessment of diuretic activity}

Adult Albino rats of either sex weighting $200-$ $220 \mathrm{~g}$ were divided into five groups of six animals each. Prior to experimentation, the animals were screened for any visible signs of disease (i.e. sneezing, runny nose, discoloration of skin and eyes, and lazy in movements). Only the healthy animals were selected for the study. The study 
was performed at a normal room temperature (25 $\pm 5{ }^{\circ} \mathrm{C}$ ). Before experimentation, the bladder of the rats were emptied by gentle compression of the pelvic area and by the pull of their tails $[12,13]$.

Group I (control group) was administered 10 $\mathrm{ml} / \mathrm{kg}$ of normal saline. Group II (reference group) was administered $10 \mathrm{mg} / \mathrm{kg}$ of furosemide and the test groups (III, IV and V) were administered different doses of Aa.Cr. (i.e., 10, 30 and $50 \mathrm{mg} / \mathrm{kg}$ ), respectively. All doses were prepared in the same volume of normal saline to administer the same volume in each group. The IP route was used for the administration of Aa.Cr., normal saline and furosemide because of its benefits (i.e., ease of administration and freedom to administer large volume of fluids) over other routes.

One week prior to the study, the albino rats were individually placed in the metabolic cages for 6 hours to adapt them to the experimental conditions. During the study, the animals were placed in the metabolic cages (i.e. one animal per cage) to separate urine and faeces. The volume of urine collected in graduated vials was measured at the end of $6 \mathrm{~h}$ and expressed as $\mathrm{ml} / 100 \mathrm{~g}$ of body weight per $6 \mathrm{~h}[12,13]$. We kept the animals in an isolated area away from normal flow of students to avoid the stress and other psychological-related effects on diuresis. The animal handling protocol was approved by the institutional Board of Advanced Studies (reg no. 125/IU.M.Phil/2009).

\section{Determination of electrolytes level}

A calibrated flame photometer (Coring 410, UK) was used to estimate concentration of $\mathrm{Na}^{+}$and $\mathrm{K}^{+}$in the fresh urine samples. Before estimating the electrolyte levels, the samples were filtered to remove debris and shedding. The concentration of electrolytes in the urine was expressed in parts per million (ppm) [12,14,15].

\section{Determination of $\mathrm{pH}$ of urine}

A calibrated $\mathrm{pH}$ meter (Model: WTW-Series $\mathrm{pH}$ 720) was used to estimate $\mathrm{pH}$ of the fresh urine samples $[12,16]$.

\section{Assessment of acute toxicity}

The acute toxicity study of Aa.Cr. was performed in Albino mice weighing from $18-25 \mathrm{~g}$. The control group of the mice was administered 10 $\mathrm{ml} / \mathrm{kg}$ of normal saline. The test animals were divided into five groups of five mice each, and were given increasing doses of Aa.Cr. (i.e. 250,
500, 1000, 2000 and $3000 \mathrm{mg} / \mathrm{kg}$ ). Before the administration of a higher dose, the animals in the previous group were observed for 6 hours for any visible signs of toxicity and mortality. All treatments were administered by oral gavage. The animals were observed closely for 2 hours, then at 30 minute intervals for 6 hours for any visible signs of toxicity (i.e. salivation, lachrymation, ptosis, squinted eyes, writhing, convulsions, tremors, yellowing of fur, loss of hair), stress (i.e. erection of fur and exopthalmia), behavioral abnormalities (i.e. impairment of spontaneous movement, climbing, cleaning of face and ataxia, and other postural changes), aggressive behavior (i.e. biting and scratching behavior, licking of tail, paw and penis, intense grooming behavior and vocalization) and diarrhea [12,17]. Mortality of the animals was noted at end of 24 hours $[12,13,17]$.

Computation of diuretic index, Lipschitz value, saliuretic index and $\mathrm{Na}^{+} / \mathrm{K}^{+}$ratio

The following equations were used to compute these parameters $[15,16]$.

Diuretic index $=(\mathrm{UVt} / \mathrm{UVc})$

Lipschitz value $=(\mathrm{UVt} / \mathrm{UV} r)$

Saliuretic index $=(\mathrm{CUEt} / \mathrm{CUEc})$

$\mathrm{Na}^{+} / \mathrm{K}^{+}$ratio $=\left(\mathrm{UNa}^{+} / \mathrm{UK}^{+}\right)$

where $\mathrm{UVt}=$ mean urine volume of test group, $\mathrm{UVc}=$ mean urine volume of control group, $\mathrm{UVr}$ $=$ mean urine volume of reference group, CUEt $=$ concentration of electrolytes in urine of test group, $\mathrm{CUEC}=$ concentration of electrolytes in urine of control group, $\mathrm{UNa}^{+}=$concentration of $\mathrm{Na}^{+}$in urine of a group, and $\mathrm{UK}^{+}=$concentration of $\mathrm{K}^{+}$in urine of a group.

\section{Statistical analysis}

Graph Pad Prism software (Graph Pad, San Diego, USA) was used for statistical analysis. The data were expressed as mean \pm standard error of mean (S.E.M.) at $95 \%$ confidence interval $(\mathrm{Cl})$. Student t-test was applied to test difference among the groups. $P<0.05$ was considered statistically significant.

\section{RESULTS}

\section{Phytochemical profile}

Aa.Cr. was positive for alkaloids, saponins, flavonoids and tannins, while anthraquinones and coumarins were absent. 
Effect of plant extracts on urinary output of rats

IP administration of Aa.Cr. increased the urinary flow in a dose-dependent manner (Figure 1). Compared with the control group, approximately 2.3, 2.6 and 3.1 fold increase in urine output was observed in the respective test groups.

The diuretic index values of the test groups III, IV and $V$ ) were 2.3, 2.6 and 3.1, respectively. Maximum diuretic effect was observed at the dose of $50 \mathrm{mg} / \mathrm{kg}$ (table 1). The Lipschitz values showed that, compared with furosemide, the 10, 30 and $50 \mathrm{mg} / \mathrm{kg}$ doses of Aa.Cr. showed 34, 40 and $46 \%$ diuretic activity, respectively (Table 1 ).

\section{Effect of plant extract on urinary electrolyte excretion and urinary $\mathrm{pH}$}

Aa.Cr. produced significant $(p<0.001)$ natriuretic effects at the dose of 30 and $50 \mathrm{mg} / \mathrm{kg}$, respectively (Figure 2 ).

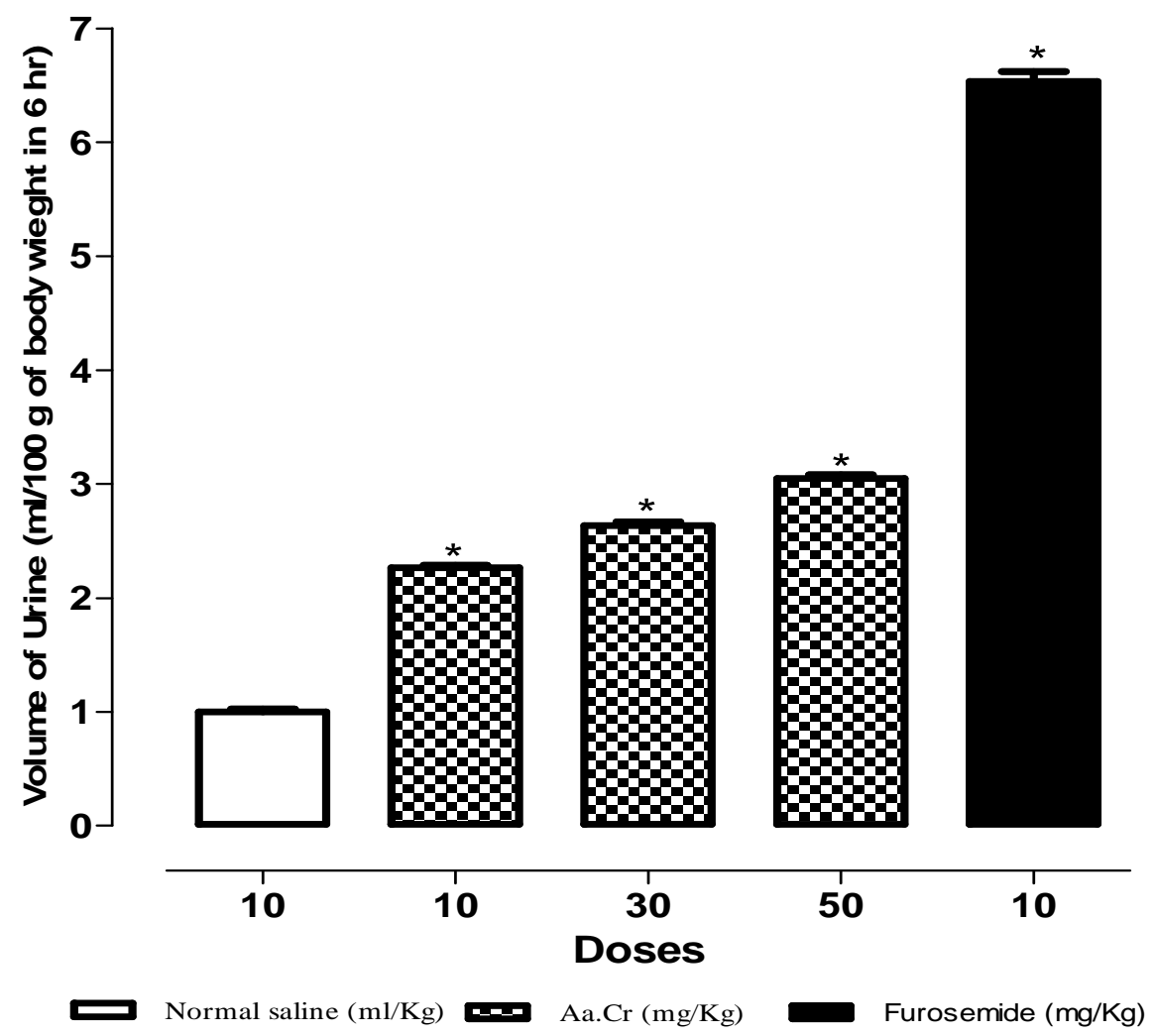

Figure 1: Effect of the Aa.Cr. on urination in Albino rats. The values shown are mean \pm S.E.M $(n=6)$ compared with control group; * $p<0.001$

Table 1: Effect of Achyranthes aspera on urinary volume and electrolyte concentrations

\begin{tabular}{|c|c|c|c|c|c|c|c|c|c|c|}
\hline \multirow[t]{2}{*}{ Group } & \multirow{2}{*}{$\begin{array}{l}\text { Extract } \\
\text { \& dose } \\
(\mathrm{mg} / \mathrm{kg})\end{array}$} & \multirow{2}{*}{$\begin{array}{c}\text { Volume of } \\
\text { urine } \\
(\mathrm{ml} / 6 \mathrm{~h})\end{array}$} & \multirow{2}{*}{$\begin{array}{l}\text { Urine } \mathrm{Na}^{+} \\
\quad(\mathrm{ppm})\end{array}$} & \multirow{2}{*}{$\begin{array}{l}\text { Urine } K^{+} \\
\text {(ppm) }\end{array}$} & \multirow[t]{2}{*}{$\mathrm{pH}$} & \multirow{2}{*}{$\begin{array}{l}\text { Diureti } \\
\text { c index }\end{array}$} & \multirow{2}{*}{$\begin{array}{l}\text { Lipschti } \\
\text { z value }\end{array}$} & \multicolumn{2}{|c|}{$\begin{array}{l}\text { Saliuretic } \\
\text { index }\end{array}$} & \multirow[t]{2}{*}{$\mathrm{Na}^{+} / \mathrm{K}^{+}$} \\
\hline & & & & & & & & $\mathrm{Na}^{+}$ & $\mathrm{K}^{+}$ & \\
\hline 1 & $\begin{array}{c}\text { Normal saline } \\
10(\mathrm{ml} / \mathrm{kg})\end{array}$ & $1.0 \pm 0.6$ & $478.3 \pm 1.6$ & $26.3 \pm 0.2$ & 7.01 & ---- & ---- & ---- & ---- & 18.38 \\
\hline 2 & Furosemide 10 & $6.6 \pm 0.5^{*}$ & $568.3 \pm 1.6^{*}$ & $48.8 \pm 0.5^{\star}$ & 7.78 & 6.6 & ---- & 1.18 & 1.84 & 11.83 \\
\hline 3 & Aa.Cr. 10 & $2.3 \pm 0.2^{*}$ & $481.7 \pm 1.6$ & $32.1 \pm 0.5^{\star}$ & 6.96 & 2.3 & 0.34 & 1.00 & 1.23 & 15.03 \\
\hline 4 & Aa.Cr. 30 & $2.6 \pm 0.1^{*}$ & $508.3 \pm 1.6^{*}$ & $39.1 \pm 0.5^{*}$ & 6.91 & 2.6 & 0.40 & 1.06 & 1.50 & 13.02 \\
\hline 5 & Aa.Cr. 50 & $3.1 \pm 0.1^{*}$ & $515.0 \pm 2.2^{*}$ & $41.8 \pm 0.1^{*}$ & 7.01 & 3.1 & 0.46 & 1.07 & 1.57 & 12.56 \\
\hline
\end{tabular}

Values given are as mean \pm S.E.M of six observations. All the values are compared with the control group (normal saline treated); $p<0.001$ 


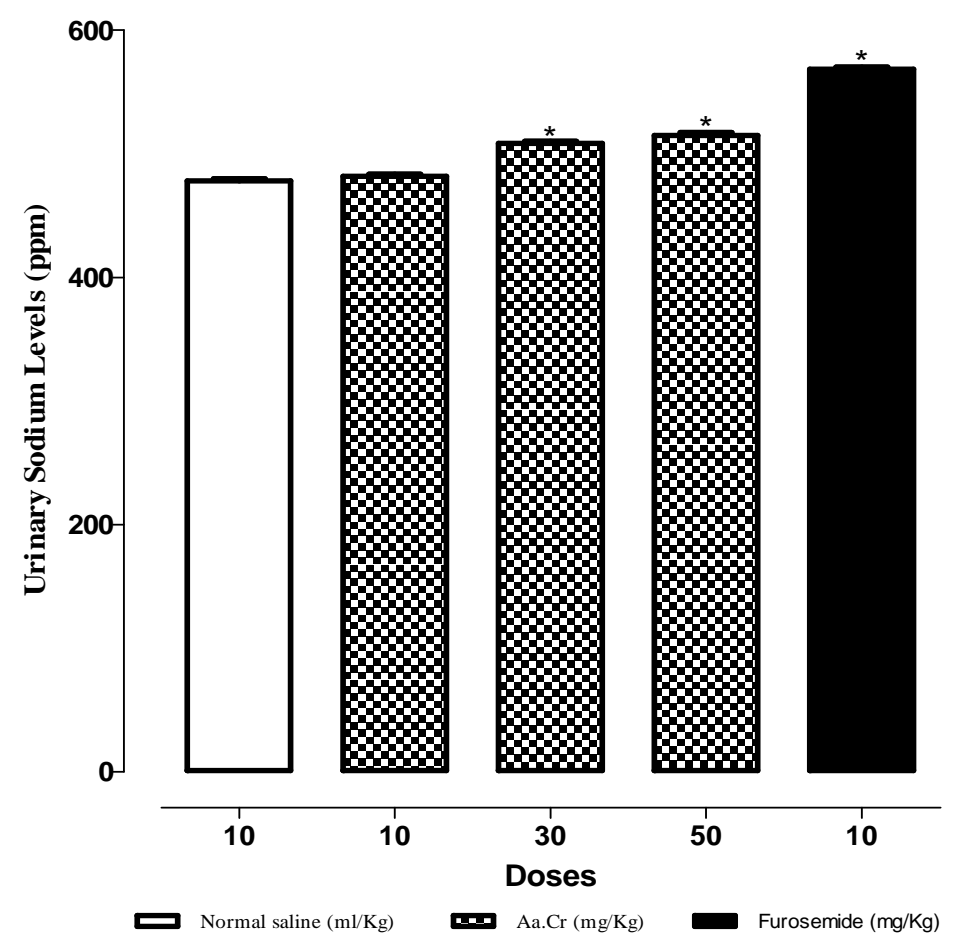

Figure 2: Effect of the Aa.Cr. on sodium levels in urine excreted during 6 h. Values are mean \pm SEM $(n=6)$ compared with control; * $p<0.001$

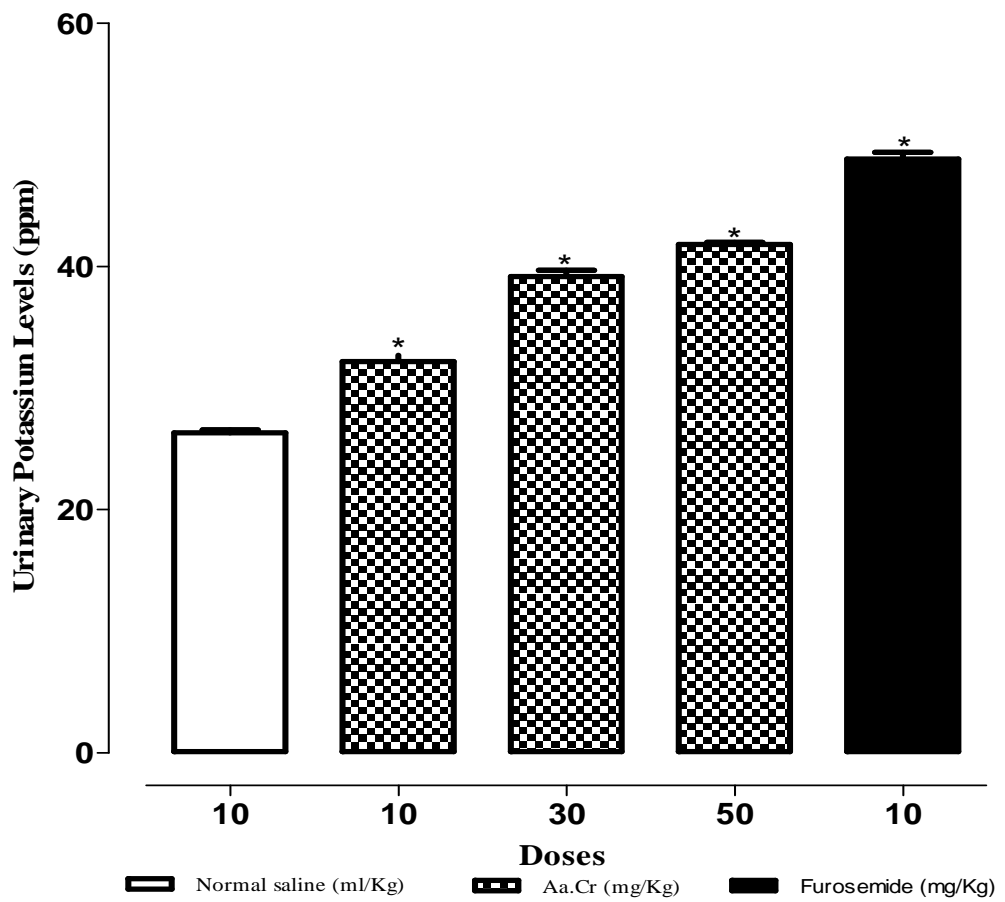

Figure 3: Effect of Aa.Cr. on potassium levels in urine excreted during 6 h. Values are mean \pm SEM $(n=6)$ compared with control; * $p<0.001$

Dose-dependent increase in the excretion of urinary $\mathrm{K}^{+}$was observed after the IP administration of Aa.Cr. (Figure 3). The saliuretic index values also showed a dose-dependent increase in the excretion of $\mathrm{Na}^{+}$and $\mathrm{K}^{+}$in the urine samples of the treated groups. 
The $\mathrm{pH}$ of fresh urine samples in the control and treated groups was not significantly different (Table 1).

\section{Acute toxicity}

The acute toxicity study in Albino mice showed that Aa.Cr. was safe even at a dose of 3000 $\mathrm{mg} / \mathrm{kg}$ of body weight. We did not find any visible signs of toxicity or any other abnormal behavior in the test animals.

\section{DISCUSSION}

Aa.Cr. is extensively studied for a variety of secondary metabolites, and it is reported to contain alkaloids, flavonoids, steroids, terpenoids and saponins. The sugar moiety of the saponin is composed of glucose, galactose, xylose and rhamnose $[9,10]$. Our preliminary phytochemical investigation revealed the presence of alkaloids, flavonoids, saponins and tannins in the Aa.Cr. Various studies have explained that the flavonoids, saponins, alkaloids and organic acids are responsible for the diuretic activity of a plant extract [11]. Such findings advocate that the presence of these secondary metabolites might be responsible for the diuretic activity of Aa.Cr.

Diuretics are usually used for the treatment of pathological conditions like nephritic syndrome, hepatic cirrhosis, congestive heart failure and hypertension [6]. It is now evident that the renal dysfunction is a common comorbidity accompanying the uncontrolled hypertension. By controlling high blood pressure, progression of renal disease may be halted. Likewise, the antioxidants are scientifically proved to have renoprotective effects in numerous animal models and may be administered as an adjuvant therapy to hypertensive patients with compromised renal function. Within this context, plants like Achyranthes aspera [18] containing secondary metabolites with diuretic and antioxidant activities are expected to be the ideal candidates for the treatment of hypertension associated with renal disorders. The results of our study showed that Aa.Cr. has notable diuretic effects in the given animal model. The maximum diuretic effects were observed at the dose of 50 $\mathrm{mg} / \mathrm{kg}$.

Patel et al stated that if the diuretic index value is $>1.50$, it indicates a good diuretic activity. Whereas the diuretic index values ranging from $1.00-1.50$ and $0.72-0.99$ demonstrate moderate and mild diuretic activity, respectively. A diuretic index value of $<0.72$ indicates no diuretic activity [11]. In the present study, the diuretic index values of the treated groups (III - V) were 2.3, 2.6 and 3.1, respectively. Thus, the extract demonstrated 3 times increase in urine volume. Lipschitz values showed that at maximal dose $(50 \mathrm{mg} / \mathrm{kg}$ ), the plant showed $46 \%$ of diuretic activity as compared with furosemide. This finding advocated that there is a need for further fractionation and isolation of pure secondary metabolite responsible for the diuretic activity of this plant extract.

In primary hypertension, $\mathrm{Na}^{+}$is considered to be one of the important external factors. Increased $\mathrm{Na}^{+}$uptake has been known to produce adverse effects on arterial blood pressure [19]. Our study showed that, compared with the saline treated group, the IP administration of Aa.Cr. produced significant natriuretic effects especially at the doses of $30 \mathrm{mg} / \mathrm{kg}$ and $50 \mathrm{mg} / \mathrm{kg}$. However, at the dose of $50 \mathrm{mg} / \mathrm{kg}$, the amount of urinary $\mathrm{Na}^{+}$ was significantly lower than that of the reference standard indicating lower probability of hyponatremia in Aa.Cr. treated animals, which is indeed a common problem associated with thiazide diuretics [6]. Similarly, $\mathrm{K}^{+}$in the urine samples significantly increased with the increasing dose of Aa.Cr. However, it is noteworthy that excretion of $\mathrm{K}^{+}$in the treated groups was less than that of the reference group suggesting potassium-sparing properties of Aa.Cr. Based on these findings, it is hypothesized that the diuretic action of Aa.Cr. might be the consequence of inhibition of epithelial sodium channels or aldosterone action [12]. Nevertheless, future studies could explore the mechanism of action at molecular level.

In 2010, Anjuna et al reported the spermatotoxic effects of $58 \mathrm{KDa}$ protein (Ap) isolated from alcoholic extract of Achyranthes aspera [20]. However, irrespective of the fact that such an activity has not been reported with aqueous extract, the traditional use of Aa.Cr. should be discouraged unless the pure phytochemical constituents responsible for diuretic activity are separated.

\section{CONCLUSION}

The present study indicates that Aa.Cr. has a strong potential as an ideal diuretic. However, further studies are required to separate the antireproductive and diuretic phytochemical constituents to confirm its safe use in renal disorders.

\section{ACKNOWLEDGEMENT}

We would like to thank Professor Dr Karamat Mehmood at Department of Chemistry, IUB for 
his valuable contribution in urinary electrolyte analysis. We are extremely thankful to laboratory staff at the Department of Pharmacy, IUB, for the supply of chemicals, reagents and animals. The bench work was performed at the Department of Pharmacy, the Islamia University of Bahawalpur, Punjab, Pakistan.

\section{REFERENCES}

1. Farnsworth $N R$, Akerele $O$, Bingel $A S$, Soejarto $D D$, Guo ZG. Medicinal Plants in Therapy. Bull World Health Org 1985; 63(6): 965-981.

2. Haq I. Safety of Medicinal Plants. Pak J Med Res 2004; 43(4): 203-210.

3. Haq F, Ahmad H, Alam M. Traditional uses of medicinal plants of Nandiar Khuwarr catchment (district Battagram), Pak J Med Plants Res 2011; 5(1): 39-48.

4. Shinwari ZK. Medicinal plants research in Pakistan. $J$ Med Plants Res 2010; 4(3): 161-176.

5. Gilani AH, Atta-ur-Rahman. Trends in ethnopharmacology. J Ethnopharmacol 2005; 100: 43-49.

6. Howland RD, Mycek MJ. Lippincott's Illustrated Reviews: Pharmacology, 3rd ed. Philadelphia: Lippincott Williams and Wilkins; 2006; pp 261-266.

7. Usmanghani K, Saeed A, Alam MT. Indusyunic Medicine: Traditional Medicine of Herbal, Animal and Mineral Origin in Pakistan. University of Karachi, Pakistan: B.C.C. and T. Press, 1997; pp 83-84.

8. Nadkarni KM. Indian Materia Medica, Vol I. Mumbai: Popular Prakashan; 2005; pp 21-22.

9. Sumeet $D$, Raghvendra $D$, Kushagra M. Achyranthes aspera Linn. (Chirchira): A magic herb in folk medicine. Ethnobotanical Leaflets 2008; 12: 670-676.

10. Goyal BR, Goyal RK, Mehta AA. Phyto-pharmacology of Achyranthes aspera: A Review. Pharmacogn Rev 2007; 1(1): 143-150.
11. Patel U, Kulkarni M, Undale V, Bhosale A. Evaluation of diuretic activity of aqueous and methanol extracts of Lepidium sativum garden cress (Cruciferae) in rats. Trop J Pharm Res 2009; 8(3): 215-219.

12. Asif M, Atif M, AMS Abdul Majid, Zahari $C D$, Irshad $A$, Ashfaq A. Diuretic activity of Trianthema portulacastrum crude extract in albino rats. Trop $J$ Pharm Res 2013; 12(6): 967-972.

13. Ratnasooriya WD, Pieris KP, Samaratunga U, Jayakody $J R$. Diuretic activity of Spilanthes acmella flowers in rats. J Ethnopharmacol 2004; 91: 317-320.

14. Sathianarayanan S, Jose A, Rajasekaran A, George RM, Chittethu $A B$. Diuretic activity of aqueous and alcoholic extracts of Wrightia tinctoria. Phytomedicine 2011; 2: 7-8.

15. Danamma KAK, Jayasimha BG, Basha SN. Diuretic activity and study of biochemical parameters in the methanol extract of Hibiscus esculentus (Okra) fresh fruits. Int J Pharma Bio Sci 2011; 1: 160-169.

16. Abdala $S$, Martín-Herrera $D$, Benjumea $D$, Gutiérrez $S D$. Diuretic activity of some Smilax canariensis fractions. J Ethnopharmacol 2012; 140: 227-281.

17. Asif $M$, Jabeen $Q$, Abdul Majid AMS, Atif M. Diuretic activity of Boswellia serrata Roxb. oleo gum extract in albino rats. Pak J Pharm Sci 2014; 27(6): 1811-1817.

18. Nehete JY, Deshmukh VN, Shewale VV, Narkhede MR, Aurangabadkar VM. In vitro antioxidant activity of Achyranthes aspera L. J Pharm Res 2009; 2(9): 1402-1403.

19. Horacio J, Adrogue MD, Nicolaos E. Madias MD. Mechanisms of disease. Sodium and potassium in the pathogenesis of hypertension. New Eng $\mathrm{J}$ Med 2007; 356: 1966-1978.

20. Anuja MNMK, Nithya RNSA, Rajamanickam C, Madambath I. Spermatotoxicity of a protein isolated from the root of Achyranthes aspera - A Comparative Study with Gossypol. Contraception 2010; 82(4): 385390. 